\title{
Self-Regulation Learning Variables and Learners' Performance: A Correlational Analysis
}

\section{Leni D. Magsino}

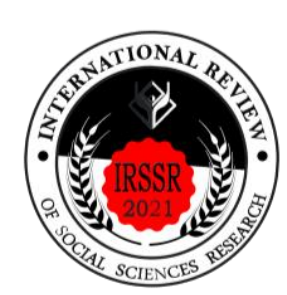

\begin{abstract}
The study evaluated the self-regulation related variables and the learners' performance to determine any significant relationship. Through descriptive-correlational design, the data were generated from the 250 Grade 9 students of Dolores Macasaet National High School for the school year 2018 - 2019. The various statistical treatments were arithmetic mean and Pearson Product Moment Correlation. The results showed that the students' self-regulation were "moderately high" in memory strategy, goal setting, self-evaluation, seeking assistance, environmental structuring, learning responsibility and organizing. Moreover, the manifested learners' performance in terms of motivation, cognition, and behavior were also "moderately high". It was further revealed that there is a significant relationship between the selfregulation variables and the learners' performance. It is recommended to develop a program that will stabilize or strengthen the students' motivation to self-regulate in terms of learning. This can be included in all aspects of classroom management. Further research using a standardized or validated questionnaire can further strengthen the findings of this study.
\end{abstract}

Keywords:

self-regulation, learners' performance, motivation, cognition, behavior

Suggested Citation: Magsino, L.D. (2021). Self-Regulation Learning Variables and Learners' Performance: A Correlational Analysis. International Review of Social Sciences Research, Volume 1, Issue 2, pp. 34- 57.

\section{About the author:}

Teacher, Dolores Macasaet National High School, Philippines 


\section{Introduction}

The Department of Education (DepEd) has mandated all public schools in the Philippines to improve the quality of learning in all aspects by continuously improving instruction and assessment of learning as stipulated in the Department Order No. 8 s. 2015. It also stresses the importance of conducting research in relation to improving classroom practices. It has allotted funds for approved researches in the district, division and national levels through BESRA (Basis Education Research Agenda). Principals and other school leaders have been instructed to support DepEd's agenda to improve the quality of learning. However, despite these efforts, quality education is still far to be reached. This has been evident by the results of international surveys such as TMDE (Test, Measurement, and Diagnostic Equipment) Integrated Maintenance Management System (TIMMS) in 2012 to which the country is second to the last among the countries surveyed in terms of Mathematics and Science efficiency of the Filipino students. More so, the results of the National Achievement Test for the last five years are not improving, as a matter of fact, these continue to decline.

In the school setting, some notable improvements in different areas have been installed in terms of infrastructure and facilities, however, there has been no significant improvement noted in terms of academic achievement. For example, the Office of the Guidance Counselor in Dolores Macasaet National High School, a public school in Quezon Province, records a declining test scores in the National Achievement Test for the last five years. More so, dropout problem is still evident.

Various factors interplay that affect the academic performance of students. As argued by Garcia (2017), some of the factors affecting students' performance include home, school, teacher and student factors. Of these, students' factors are highly associated with the academic performance (Almerino, et al., 2020; Sicat \& Panganiban, 2009; Lansangan, et al., 2015; Mangaoil, 2018). In the public school setting, many cases of quarrels have been forwarded to the guidance office. Many of which can be traced to lack of social skills being possessed by the students. Another cause of the problem is lack of understanding oneself. Many students do not know who they are. Some of them rebel against the world they are living with for lack of such understanding. When this happens, this results to problems in 
academic aspects. Problems become more complicated. For this, understanding oneself is a key to understanding others. This can be developed through a well-developed self-esteem on the part of the students.

This study presumes that the basic step to understanding the academic problem is the determination of the students' level of self-regulation. This will be the fundamental step in effective decision-making processes. Academic policies may be modified in relation to the self-regulation that students have. When this will be correlated to academic performance, sound academic policies would be possibly developed to improve school achievements.

This study assessed the self-regulation level of the Grade 9 students of Dolores Macasaet National High School in terms of memory strategy, goal setting, self-evaluation, seeking assistance, environmental structuring, learning responsibility and organizing. It also assessed the learners' performance in terms of motivation, cognition and behavior to determine any significant relationship with the self-regulation variables.

\section{Literature review}

\subsection{Self-regulation and Self-regulated learners}

Hayon (2008) said that self-regulation usually refers to awareness and knowledge of one's learning and cognition and the control of one's cognition that renders this ability essential in learning and development. Recently, the concept has been studied intensively, except in professional learning. This is believed to be essential in student teacher learning since prospective teaching professionals are likely to be confronted with different challenges of learning and the learners. It is high time that they developed a sense of responsibility that aims to know every learner under their jurisdiction.

Zumbrunn, Tadlock and Roberts (2011) said that self-regulated learning (SLR) is recognized as an important predictor of student academic motivation and achievement. This process requires students to independently plan, monitor, and assess their learning. However, few students naturally do this well. Self-regulated learning is a process that assists students in managing their thoughts, behaviors, and emotions in order to successfully navigate their learning experiences. This process occurs when a student's purposeful actions and processes are directed towards the acquisition of information or skills. Research shows that selfregulated students are more engaged in their learning. These learners commonly seat 
themselves toward the front of the classroom, voluntarily offer answers to questions, and seek out additional resources when needed to master content. Most importantly, selfregulated learners also manipulate their learning environments to meet their needs. Due to their resourcefulness and engagement, it is not then surprising that findings from recent studies suggest that self-regulated learners also perform better on academic tests and measures of student performance and achievement (Zimmerman, 2010).

\subsection{Domains of Self-regulation}

\subsubsection{Memory Strategy}

Memory strategies (traditionally known as mnemonics) have been found to enhance remembering through the connection of new knowledge with familiar words and images. Memory strategies, as one of the most effective strategies in the vocabulary learning process are extremely powerful mental tools. They include activities for remembering and retrieving the new information such as acronyms, key words, images etc. They help the learner to link the second language item with the new one. In the study of Ghorbani (2011) that memory strategy instruction is useful for the long-term vocabulary retention. Since teaching memory strategies seems to have facilitated the process of long-term vocabulary retention, the findings are in line with Nemati (2009), Schmitt and Schmitt 1995), and Craik and Tulving (1972). However, they are different from Marefat and Shirazi's (2003) findings in which learners who received memory strategy instruction performed better in short-term retention test than long-term retention test. In Sozler's (2012) investigation, the results of the study suggest that successful vocabulary learning depends on the ways they are practiced. It has been proved that memory strategies help learners to integrate with the language and learn the vocabulary, which helps to recall them easily in the following phases of language teaching.

\subsubsection{Goal Setting}

Goals can be thought of as the standards that regulate an individual's actions (Schunk, 2010). In the classroom, goals may be as simple as earning a good grade on an exam, or as detailed as gaining a broad understanding of a topic. Short-term attainable goals often are used to reach long-term aspirations. Research also suggests that encouraging students to set short-term goals for their learning can be an effective way to help students track their 
progress. Similar to goal setting, planning can help students self-regulate their learning prior to engaging in learning tasks as this can help learners establish well thought out goals and strategies to be successful (Schunk, 2010). Teaching students to approach academic tasks with a plan is a viable method for promoting self-regulation and learning. Academically selfregulated students take time to plan. They know how to use time frames to schedule and pace their academic activities (Bandura \& Cervone, 1986).

In the study of Morisano, Hirsh, Peterson, Pihl, \& Shore (2018) it was found that setting goals and reflecting upon them improves academic success. Dotson (2015), based on his study, asserted that setting goals keeps students focused on desired outcomes and provides a clear direction for success. The key to establishing goals that produce results is making them specific, measureable, attainable, relevant, and time sensitive. Furthermore, goals must be supported by a specific plan of action that outlines the steps to be taken to maximize success.

\subsubsection{Self-Evaluation}

Andrade (2017) defines self-evaluation as the act of monitoring one's processes and products in order to make adjustments that deepen learning and enhance performance. Student self-evaluation is the process by which the students gather information about and reflect on their own learning and is considered to be a very important component of learning. It occurs in the absence of external rewards or incentives and can therefore be a strong indicator that a learner is becoming more autonomous. By establishing their own learning goals and finding motivation from within to make progress toward those goals, students are more likely to persist through difficult learning tasks and often find the learning process more gratifying (Zimmerman, 2010).

Wiliam and Black (2010) study indicated that self-assessment and self-directed learning would have an effect on student's academic performance. Students are more likely to become self-regulated learners when they are able to evaluate their own learning, independent of teacher-issued summative assessments. This practice enables students to evaluate their learning strategies and make adjustments for similar tasks in their future. Teachers can promote self-evaluation in the classroom by helping students monitor their 
learning goals and strategy use, and then make changes to those goals and strategies based upon learning outcomes (Zimmerman, 2014).

\subsubsection{Attention Control}

In order to self-regulate, learners must be able to control their attention. Attention control is a cognitive process that requires significant self-monitoring. Often this process entails clearing the mind of distracting thoughts, as well as seeking suitable environments that are conducive to learning (e.g., quiet areas without substantial noise). Research indicates that students' academic outcomes increase with focused time spent on-task. Thus, teaching students to attend to learning tasks should be a priority. Teachers can help their students control their attention by removing stimuli that may cause distractions, and providing students with frequent breaks to help them build up their attention spans.

Students who are academically self-regulated understand and use problem-solving strategies. They select strategies to achieve their goals, sequence the strategies selected, set standards to gauge the quality of their performance, manage their attention, and monitor the degree to which they are acting in accordance with their standards and making progress in achieving their goals. If they become frustrated along the way, these students work to overcome the problem. They do not procrastinate and are aware of discrepancies among their actions, goals, and performance standards. When discrepancies are noted, academically selfregulated learners use this information to adjust their efforts and strategies. In addition, they try to take advantage of the help available and use routines and structure to help get their work done.

\subsubsection{Self-Monitoring}

To become strategic learners, students must assume ownership for their learning and achievement outcomes (Kistner et al., 2010). Self-regulated learners take on this responsibility by monitoring their progress towards learning goals. The process of selfmonitoring encompasses all of the aforementioned strategies. In order for a learner to selfmonitor their progress, they must set their own learning goals, plan ahead, independently motivate themselves to meet their goals, focus their attention on the task at hand, and use learning strategies to facilitate their understanding of material. Teachers can encourage self- 
monitoring by having students keep a record of the number of times they worked on particular learning tasks, the strategies they used, and the amount of time they spent working. This practice allows students to visualize their progress and make changes as needed.

\subsubsection{Seeking Assistance}

Contrary to popular belief, self-regulated learners do not try to accomplish every task on their own, but rather frequently seek help from others when necessary. What sets selfregulated learners apart from their peers is that these students not only seek advice from others, but they do so with the goal of making themselves more autonomous. Teachers can promote positive help seeking behaviors by providing students with on-going progress feedback that they can easily understand and allowing students opportunities to resubmit assignments after making appropriate changes.

In summary, self-regulated learners are able to set short- and long-term goals for their learning, plan ahead to accomplish their goals, self-motivate themselves, and focus their attention on their goals and progress. They also are able to employ multiple learning strategies and adjust those strategies as needed, self-monitor their progress, seek help from others as needed, and self-evaluate their learning goals and progress based upon their learning outcomes. Teachers at the primary and secondary levels can use the aforementioned strategies to promote self-regulation in their classrooms. However, teachers should understand that learners develop at various paces, and strategies that work best for one learner may not always work with the next.

\subsubsection{Environmental Structuring}

According to Mutua (2010), the distribution of secondary school students' performance in public examinations has been skewed towards the lower grades. This poor performance has been majorly attributed to school environmental factors and little has been done on individual psychological factors which may contribute towards students' academic achievement. The study was therefore designed to determine students' academic motivation and self-regulated learning as predictors of academic achievement. The main aim was to determine a prediction model of secondary school students' academic achievement given academic motivation and self-regulated learning. More specifically, the relationship among academic motivation, self-regulated learning and academic achievement was established. 


\subsubsection{Learning Responsibility}

Responsibility has been defined in different ways in the literature. One of these definitions is, people assume the consequences of any event or behavior within its own limit of authority (TDK, 2014). According to Yiğittir's (2010) study, results have showed that parents of elementary students wish that responsibility value can be acquired in schools. Families have important roles in children gaining the responsibility value. Families can be taught in primary schools about the importance of value education, families roles when making children gain values, supporting the values at home in the context of school-family cooperation.

According to Farrington et al.( 2012), not only in utilizing approaches that encourage growth of discrete skills or strengths such as self-regulation and collaboration, educators can shape students' overall attitude towards and beliefs about school. These academic mindsets strongly influence student behaviors, and thus, academic outcomes. They include students' beliefs about the value of school and how much they feel they belong, succeed, and grow there. Mindset is an area in which, compared to individual non-curricular learning skills, there is more of a research base describing successful interventions. Academic mindsets might not at first sound skill-related, but these mindsets can be taught and developed. Furthermore, programs that target academic mindsets have encouragingly been shown to not only improve academic performance, but also to indirectly contribute to the growth of other non-curricular learning skills.

\subsection{Self-Regulation and Academic Performance}

Wolters (2013) said that self-regulated learning concerns the application of general models of regulation and self-regulation to issues of learning especially within academic contexts. Rio et. al (2017) state that learning to learn and learning to cooperate are two important goals for individuals. Moreover, self-regulation helps to prevent school failure. Learners high on self-regulation, both high and low-achieving, tend to exhibit a high sense of efficacy in their own capabilities. Therefore, schools should try to improve both, selfregulation and self-efficacy, to prevent school failure, because every student needs to feel the support to develop the belief that he/she can improve his/her knowledge and skills and learn. 
Lavasoni et al (2011) investigated the effects of self-regulation learning strategies training on the academic motivation and self-efficacy of students. The results of the study indicated that the teaching of self-regulation learning strategies has had a significant effect on the academic motivation and self-efficacy of the students. Meanwhile, Dent and Koenca (2015) explored how academic achievement relates to two main components of selfregulated learning and found that correlations significantly differed based on the specific process or strategy, academic subject, grade level, type of self-regulated learning measure, and type of achievement measure.

According to Patrick et al. (2007), adaptive cognitive and metacognitive engagement are defining features of self-regulated learning. Although several studies have explored students' use of cognitive and metacognitive strategies, few have tested their relative influence on academic achievement. Students' use of cognitive strategies has been found to improve academic performance across different grade levels and subject areas. However, the self-regulation of these strategies may be more important. While cognitive strategies help students understand and retain academic material, metacognitive processes ensure that they have done so. Without self-monitoring, students would not realize that their comprehension of the material falls short of a learning goal. Without self-control, students could not take the needed steps to improve it. Cognitive strategies are thus the tools in a student's repertoire that are necessary to perform a task. However, choosing the most appropriate tools and making sure they accomplish the task goal are necessary to perform it well. Therefore, academic performance is expected to have a stronger association with the metacognitive processes of self-regulated learning than the use of cognitive strategies. However, the extent to which selfregulated learning influences academic achievement depends on the type of schoolwork. Put simply, academic tasks must demand metacognitive processes and cognitive strategies in order for using them to improve performance (Patrick et al. 2007).

Students who are behaviorally engaged would normally comply with behavioral norms, such as attendance and involvement, and would show the absence of disruptive or negative behavior. So, behavioral engagement can be seen from the behavioral norms of the students. In addition, Mintz (2009) states that survey questions that are grouped within this dimension of engagement include questions about homework, preparation for class, classroom discussions and assignments, and the level of academic challenge that students 
report. It means that the behavioral engagement of the students includes their behavior in class activity, such as: the students' contribution in class, the students' performance, etc. Moreover, based on Lester's (2011) opinion, the involvement in learning and academic tasks comprise student behaviors related to concentration, attention, persistence, effort, asking questions, and contributing to class discussions.

\section{Methodology}

This study used descriptive-correlation design. The study employed descriptive method design in the form of a survey questionnaire. A set of questionnaire was prepared for the students aimed at assessing their own level of self-regulation. This was likewise correlated with their learners' performance.

The study employed questionnaire as the research instrument used in gathering pertinent data. The self-regulation learning tool in academics was used to determine the selfregulation level of the students. This was composed of the following components: memory strategy, goal setting, self-evaluation, seeking assistance, environmental structuring, learning responsibility and organizing.

The participants of the study were Grade 9 students of Dolores Macasaet National High School. Through the use of Slovin's formula in determining sample size, a total of 250 students were chosen as participants. This comprises $89 \%$ of the total population. There were 127 female and 123 male students whose parents' combined family income are mostly more than P 5, 000.00 (USD105) a month.

The various statistical treatments used in this study were arithmetic mean and Pearson Product - Moment Correlation.

\section{Findings and Discussion}

Table 1 shows the summary of the respondents' perception on the self-regulation variables. Based on the table, the respondents generally agree on all statements as shown in the overall mean summary of 3.743 interpreted as "Moderately High". 


\section{Table 1}

The Respondents' Perception on Self- Regulation

\begin{tabular}{cccc}
\hline Indicators & $\mathbf{x}$ & SD & Interpretation \\
\hline Memory Strategy & 3.73 & 0.95 & Moderately High \\
Goal Setting & 3.74 & 0.75 & Moderately High \\
Self-Evaluation & 3.66 & 0.39 & Moderately High \\
Seeking Assistance & 3.73 & 0.24 & Moderately High \\
Environmental Structuring & 3.81 & 0.25 & Moderately High \\
Learning Responsibility & 3.72 & 0.32 & Moderately High \\
Organizing & 3.81 & 0.31 & Moderately High \\
\hline Overall & $\mathbf{3 . 7 4 3}$ & $\mathbf{0 . 4 5 9}$ & Moderately High \\
\hline
\end{tabular}

In terms of memory strategy, the respondents' level of self-regulation in terms of memory strategy is moderately high as shown in the overall mean computation of 3.73 . Results of the assessment imply that the respondents can more likely be described as "visual" learners because they need to construct symbols through writings, drawings and organizers for them to easily remember ideas they hear from class activities and they do not prefer audio-video recording of the lesson.

Meanwhile, in goal setting, the respondents manifested a moderately high level of self-regulation in terms of goal setting as shown in the overall mean of 3.74 . In particular, participants of the study set goals for learning through thinking always of their goals and the possible output whenever they do important tasks. On the other hand, the least they do in terms of setting goals although in a moderately high level scale is making the list of things to do each day. This validates the kind of visual learners the students are. They may just want to think what they want to accomplish each day. They don't necessarily have to write all of them. It could be inferred from this result that the students lack the discipline of organizing their work load or academic tasks that could somewhat lead to poor academic performance. It has been observed in various studies that making plans entail organizing your task that 
includes listing of daily tasks is an effective tool of improving one's performance. When one does listing of tasks and checking them daily if everything has been complied then one would not have the chance to miss something that is important. In the classroom setting, this could mean not forgetting any important class activity or task to do, to complete and to submit to the teacher. This means attaining all the goals one has set for the achievement of something.

In self-evaluation, the respondents manifested a moderately high level of selfregulation in terms of self-evaluation as shown in the overall mean computation of 3.66 . Specifically, they assess their own learning by examining their own work which involves a lot of reflection as far as the learning activity is concerned. For learners to evaluate themselves, they need to ponder about their performance. While it may be true that they examine their own work, they may not do it through compiling them for personal evaluation. As it was clearly shown that these respondents are not keen on writing. Another possible reason is their economic status, most of them belong to poor family income groups to which it might be very difficult for them to buy materials for such.

In terms of seeking assistance, the respondents exhibit a moderately high level of selfregulation in terms of seeking assistance as shown in the overall mean computation of 3.73 . The learners' way of seeking assistance to learn more is through listening from feedback coming from authorities on the subject matter such as teachers and significant others whom they think are knowledgeable about the subject matter. They also understand the role of feedback in improving their work as students. On the other hand, the least they do in terms of seeking assistance is they use library resources to find necessary data for their work. This may be due to the fact that there is lack of library materials in the school. Most of them rely heavily on information provided in the internet which are easy to access anytime aside from 
the fact that it is convenient. Another possible reason for this occurrence may be attributed to poor economic condition of the respondents.

In environmental structuring, the respondents generally exhibited a moderately high level of self-regulation in terms of environmental structuring as shown in the overall mean computation of 3.81. Specifically, they read instructions carefully before doing any task $(m=4.04)$. On the other hand, the least they do in terms of environmental structuring is that they listen to music attentively when they study $(\mathrm{m}=3.51)$. It could be deduced that these learners want an environment that is conducive to their own learning. Actually, they make it themselves. Distractions hamper learning development.

In terms of learning responsibility, the respondents generally manifested a moderately high level of self-regulation with an overall mean of 3.72. They do assigned task before doing any personal matters $(m=3.88)$ but they do not prefer to allot time to study lessons every night $(m=3.55)$. Results show that the respondents manifested responsibility towards learning. This is a good indication that they voluntarily subject themselves to different learning experiences. Such responsibilities as manifested exist because of many factors that collaborate with one another.

In organizing, the respondents manifested organizing skills in a moderately high level as forms of their self-regulation learning as shown in the overall mean of 3.81. They develop plan for the solution of a problem $(\mathrm{m}=3.96)$ but have less preference on figuring out goals and things to do to accomplish them $(\mathrm{m}=3.63)$. Based on their less preferred self-regulation tasks in terms of organizing, it could be deduced that the respondents are not keen on cognitive aspects of planning or figuring out the necessary things to do in terms of learning. 
Table 2

Summary of Respondents' Perception on their Performance

\begin{tabular}{cccc}
\hline Indicator & $\mathbf{X}$ & SD & Interpretation \\
\hline Cognition & 3.73 & 0.35 & Moderately High \\
Motivation & 3.80 & 0.39 & Moderately High \\
Behavioral & 3.73 & 0.24 & Moderately High \\
\hline Overall & $\mathbf{3 . 7 5}$ & $\mathbf{0 . 3 3}$ & Moderately High \\
\hline
\end{tabular}

Table 2 shows the mean summary of learners' performance of the respondents in terms of cognition, motivation and behavior. The overall mean of 3.75 shows that the respondents generally agree with the statements. It means that they exhibited academic performance within the moderately high level.

The respondents perform cognitive activities on a moderately high level of cognition as shown in the overall mean of 3.73. Specifically, they are able to comprehend what they have read $(\mathrm{m}=3.85)$ and can evaluate concepts and products at a moderately high level $(m=3.60)$. The respondents' cognitive function may be said to be increasing when they are exposed to concrete and tangible facts, that is, they learn best when they actually see the subject of their learning experiences. It could be thought that these respondents are actually visual learners based on the results of previous analyses. Visual learners needed to be shown actual or related symbols just to understand fully what they symbolize as an object of learning.

Meanwhile, the respondents manifested activities that improve motivation in relation to their academic performance on a moderately high level as shown in the overall mean computation of 3.80 . They become motivated when they hear feedback about their learning 
$(m=4.05)$ while are moderately high in problem solving when it develops a solution that works $(\mathrm{m}=3.71)$.

The respondents manifested behavioral performance on a moderately high level as shown in the overall mean of 3.73. Based on the table, they learn well in a well-arranged classroom $(m=3.86)$ while they are moderately high in their recitation $(m=3.56)$. Students learn behavior by watching and imitating others. Many types of behavior detract from learning. These include talking out of turn, being out of the seat without permission, not paying attention and disrupting other students by making noise or touching them.

\section{Table 3}

Correlation between Learners' Performance and Self-Regulation Related Variables

\begin{tabular}{lccc}
\hline & Motivation & Cognition & Behavior \\
\hline 1. Memory Strategy & .386 & .477 & .444 \\
2. Goal Setting & $.505^{*}$ & $.591^{*}$ & $.545^{*}$ \\
3. Self-Evaluation & $.546^{*}$ & $.642^{*}$ & $.596^{*}$ \\
4. Seeking Assistance & $.587^{*}$ & $.655^{*}$ & $.642^{*}$ \\
$\begin{array}{l}\text { 5. Environmental } \\
\text { Structuring }\end{array}$ & $.702^{*}$ & $.718^{*}$ & $.699^{*}$ \\
$\begin{array}{l}\text { 6. Learning Responsibility } \\
\text { 7. Organizing }\end{array}$ & $.622^{*}$ & $.667^{*}$ & $.643^{*}$ \\
& $.671^{*}$ & $.675^{*}$ & $.616^{*}$ \\
\hline
\end{tabular}

** Correlation is significant at the 0.01 level (2-tailed)

* Correlation is significant at the 0.05 level (2-tailed)

Table 3 shows the correlation between learners' performance in terms of cognition, motivation and behavior and self-regulation related variables such as memory strategy, goal setting, self-evaluation, seeking assistance, environmental structuring, learning responsibility and organizing of the respondents. 
Based from the table, there is a positive low correlation between motivation and memory strategy ( $r=.386$, low positive correlation). On the other hand, there is a moderate correlation between cognition, behavior and memory strategy $(r=.477$ and $r=.444$ respectively). There is a moderate correlation between goal setting and learners' performance (such as cognition, motivation and behavior) with $\mathrm{r}=.591, \mathrm{r}=.505$ and $\mathrm{r}=.545$ respectively. There is a moderately high correlation between self-evaluation and cognition $(r=.642)$. Meanwhile, there is a low positive correlation between self-evaluation and motivation $(\mathrm{r}=.546)$ and low positive correlation also between self-evaluation and behavior $(\mathrm{r}=.596)$.

There is a moderately high correlation between seeking assistance and cognition with $\mathrm{r}=.655$ and between seeking assistance and behavior with $\mathrm{r}=.642$. On the other hand, there is a low correlation between seeking assistance and motivation with $\mathrm{r}=.587$.

There is a moderately high correlation between environment structuring and academic performance (cognition, motivation and behavior) with the $r=.718, r=.702$ and $r=.699$ respectively. There is also a moderately high correlation between learning responsibility and learners' performance (cognition, motivation and behavior) with $r=.667, r=.622$ and $r=.643$ respectively. Finally, there is also a moderately high correlation between organizing and learners' performance (motivation, cognition, and behavior) with $\mathrm{r}=.675, \mathrm{r}=.671$ and $\mathrm{r}=.616$ respectively.

\section{Conclusion}

The study assessed the self-regulation related variables and learners' performance to determine if there is a significant relationship between these variables. The respondents of the study were 250 selected Grade 9 students of Dolores Macasaet National High School for the school year 2018-2019. The study utilized descriptive design of research using 
questionnaire as the main tool to gather data needed in the study. The weighted arithmetic mean and Pearson $r$ were the main statistical tools used to treat data gathered in the study.

The results showed that the respondents' self -regulation were "moderately high" in all variables of self-regulation such as memory strategy, goal setting, self-evaluation, seeking assistance, environmental structuring, learning responsibility and organizing. As to the learners' performance in terms of motivation, cognition, and behavior, they are generally "moderately high". It was further revealed that there is a significant relationship between the self-regulation variables and the learner's performance.

The school administrators may develop a program that will stabilize or strengthen more students' motivation to self-regulate in terms of learning. They may also include SelfRegulated Learning program in all aspects of school management and administration and more funds to maintain a well-structured and organized learning environment. Teachers may always include Self-regulated learning program in all aspects of classroom management. They may maintain a positive learning environment to strengthen students' interest in learning and their self-regulation learning activities in the classroom. Future researchers may conduct researches of the same nature such as this to extreme population sector. They may develop a more validated questionnaire to strengthen the findings of this study. Furthermore, they may use other variables to correlate with self-regulation learning drive. 


\section{APPENDICES}

\section{Appendix A \\ The Level of their Self-Regulation as to Memory Strategy}

\begin{tabular}{llll}
\hline Indicator & Mean & SD & Interpretation \\
\hline 1. I write down information so I could easily remember them. & 4.09 & 0.82 & Moderately High \\
2. I group similar information according to their category. & 3.87 & 0.74 & Moderately High \\
3. I take down notes using my own words in writing my notes. & 3.68 & 0.81 & $\begin{array}{c}\text { Moderately High } \\
\text { Moderately High }\end{array}$ \\
4. For better comprehension, I try to illustrate my ideas through graphic & 3.69 & 0.87 & \\
organizers. & & & Moderately High \\
5. I utilize drawings and symbols that will help me in recalling the concepts & 3.80 & 0.88 & \\
and ideas I need to learn. & 3.61 & 0.87 & Moderately High \\
6. I summarize what I have read & 3.61 & 0.96 & Moderately High \\
7. I usually write an outline of the topics that we have discussed in class. & 3.81 & 0.87 & Moderately High \\
8. I visualize the concepts in my mind so that I will be able to recall them. & 3.32 & 1.01 & Low \\
9. I record the video or audio of the class discussion I attended to. & 3.68 & 3.43 & Moderately High \\
10. I read aloud to recall things. & $\mathbf{3 . 7 3}$ & $\mathbf{0 . 9 5}$ & Moderately \\
\hline TOTAL & & & High \\
\hline
\end{tabular}

\section{Appendix B}

The Level of the Self-Regulation as to Goal Setting

\begin{tabular}{|c|c|c|c|c|}
\hline \multicolumn{2}{|c|}{ Indicator } & \multirow{2}{*}{$\frac{\mathbf{X}}{3.88}$} & \multirow{2}{*}{$\frac{\text { SD }}{0.87}$} & \multirow{2}{*}{$\begin{array}{l}\text { Interpretation } \\
\text { Moderately High }\end{array}$} \\
\hline 1. & I make sure to accomplish things that I need to do each day. & & & \\
\hline 2. & I make a list of things to do each day. & 3.40 & 0.94 & Low \\
\hline 3. & I plan my daily tasks. & 3.65 & 0.93 & Moderately High \\
\hline 4. & $\begin{array}{l}\text { I have personal tracking scheme to see to it that everything is done as } \\
\text { planned. }\end{array}$ & 3.70 & 0.9 & Moderately High \\
\hline 5. & $\begin{array}{l}\text { I always think of my goal and the possible output whenever I do an } \\
\text { important task. }\end{array}$ & 3.99 & 0.84 & Moderately High \\
\hline 6. & I think of my resources first before I plan any task to accomplish. & 3.74 & 0.86 & Moderately High \\
\hline 7. & My goals are clearly defined. & 3.75 & 0.89 & Moderately High \\
\hline 8. & I set deadlines for myself so that I will be able to attain my goals. & 3.80 & 0.92 & Moderately High \\
\hline 9. & I set goals that I can surely attain. & 3.72 & 0.89 & Moderately High \\
\hline 10. & $\begin{array}{l}\text { I try to identify the important parts that I need to do to be able to } \\
\text { accomplish a particular task. }\end{array}$ & 3.75 & 0.93 & Moderately High \\
\hline \multicolumn{2}{|c|}{ Overall } & 3.74 & 0.75 & Moderately High \\
\hline
\end{tabular}




\section{Appendix C}

The Level of their Self-Regulation as to Self-to Self-Evaluation

\begin{tabular}{|c|c|c|c|c|}
\hline \multicolumn{2}{|c|}{ Indicator } & \multirow{2}{*}{$\frac{\mathbf{X}}{3.45}$} & \multirow{2}{*}{$\frac{\text { SD }}{0.90}$} & \multirow{2}{*}{$\begin{array}{l}\text { Interpretation } \\
\text { Low }\end{array}$} \\
\hline 1. & I write reflective journal after accomplishing a task & & & \\
\hline 2. & $\begin{array}{l}\text { I appreciate feedback/comments/ suggestions from my teachers and } \\
\text { classmates. }\end{array}$ & 3.77 & 0.83 & Moderately High \\
\hline 3. & I evaluate my own performance based on determined criteria. & 3.68 & 0.82 & Moderately High \\
\hline 4. & $\begin{array}{l}\text { I check my own progress by reviewing and reflecting on my previous } \\
\text { performances. }\end{array}$ & 3.72 & 0.89 & Moderately High \\
\hline 5. & I examine my work. & 3.89 & 0.91 & Moderately High \\
\hline 6. & $\begin{array}{l}\text { I improve taking into account all the feedbacks/comments/suggestions I } \\
\text { receive from others. }\end{array}$ & 3.68 & 0.94 & Moderately High \\
\hline 7. & I am aware of my own progress in working effectively. & 3.58 & 0.81 & Moderately High \\
\hline 8. & $\begin{array}{l}\text { I compile my works for personal evaluation and reflection on how to } \\
\text { further improve them. }\end{array}$ & 3.41 & 1.01 & Low \\
\hline 9. & $\begin{array}{l}\text { I utilize the suggestions of others for the improvement of my } \\
\text { performance. }\end{array}$ & 3.59 & 0.9 & Moderately High \\
\hline 10. & I evaluate my own learning to continually improve myself. & 3.86 & 0.92 & Moderately High \\
\hline \multicolumn{2}{|c|}{ Overall } & 3.66 & 0.39 & Moderately High \\
\hline
\end{tabular}

\section{Appendix D}

The Level of their Self-Regulation as to Seeking Assistance

\begin{tabular}{|c|c|c|c|c|}
\hline \multicolumn{2}{|c|}{ Indicator } & \multirow{2}{*}{$\frac{\mathbf{X}}{3.82}$} & \multirow{2}{*}{$\frac{\text { SD }}{0.87}$} & \multirow{2}{*}{$\frac{\text { Interpretation }}{\text { Moderately High }}$} \\
\hline 1. & I seek experts' opinion for my own work. & & & \\
\hline 2. & $\begin{array}{l}\text { I welcome feedback for the improvement of my } \\
\text { performance. }\end{array}$ & 3.76 & 0.82 & Moderately High \\
\hline 3. & I listen attentively to people who comment on my work. & 3.88 & 0.93 & Moderately High \\
\hline 4. & I use variety of resources when doing school-related tasks. & 3.74 & 0.85 & Moderately High \\
\hline 5. & I use library resources to find necessary data for my work. & 3.59 & 0.9 & Moderately High \\
\hline 6. & $\begin{array}{l}\text { I consult my teacher whenever I don't understand } \\
\text { something in my studies. }\end{array}$ & 3.74 & 0.92 & Moderately High \\
\hline 7. & $\begin{array}{l}\text { I enjoy group work for I get a lot of learnings from group } \\
\text { mates. }\end{array}$ & 3.82 & 0.9 & Moderately High \\
\hline 8. & I compare my notes with that of my classmates. & 3.63 & 0.93 & Moderately High \\
\hline 9. & $\begin{array}{l}\text { I use study group chat to share and get ideas from each } \\
\text { other. }\end{array}$ & 3.60 & 0.92 & Moderately High \\
\hline 10. & I share ideas with my peers. & 3.74 & 0.9 & Moderately High \\
\hline \multicolumn{2}{|c|}{ Overall } & 3.73 & 0.24 & Moderately High \\
\hline
\end{tabular}




\section{Appendix E}

The Level of their Self-Regulation as to Environmental Structuring

\begin{tabular}{lllll}
\hline Indicator & $\mathbf{X}$ & SD & Interpretation \\
\hline 1. $\quad$ I want a noise-free environment whenever I review notes. & 3.93 & 0.96 & Moderately High \\
2. $\quad$ I avoid any distractions while doing schoolwork. & 3.92 & 0.78 & Moderately High \\
3. $\quad$ I find a place where I can study well. & 3.90 & 0.94 & Moderately High \\
4. $\quad$ I am very particular about task conditions. & 3.70 & 0.88 & Moderately High \\
5. $\quad$ I read instructions carefully before doing any task. & 4.04 & 0.83 & Moderately High \\
6. $\quad$ I keep working even on difficult tasks. & 3.80 & 0.87 & Moderately High \\
7. $\quad$ I listen to music when I study. & 3.51 & 1.14 & Moderately High \\
8. I want to be in the group during class activities. & I listen attentively during lecture. & 3.57 & 0.9 & Moderately High \\
9. & 3.93 & 0.8 & Moderately High \\
10. I prefer visuals during class activities. & 3.86 & 0.88 & Moderately High \\
\hline 'Overall & $\mathbf{3 . 8 1}$ & $\mathbf{0 . 2 5}$ & Moderately High \\
\hline
\end{tabular}

\section{Appendix F}

The Level of their Self-Regulation as to Learning Responsibility

\begin{tabular}{|c|c|c|c|c|}
\hline \multicolumn{2}{|c|}{ Indicator } & \multirow{2}{*}{$\frac{X}{3.65}$} & \multirow{2}{*}{$\frac{\text { SD }}{0.87}$} & \multirow{2}{*}{$\begin{array}{l}\text { Interpretation } \\
\text { Moderately High }\end{array}$} \\
\hline 1. & I always do my homework. & & & \\
\hline 2. & I recheck classwork before submitting it. & 3.80 & 0.82 & Moderately High \\
\hline 3. & I do assigned task before doing any personal matters. & 3.88 & 0.85 & Moderately High \\
\hline 4. & I submit works on or before the deadline. & 3.71 & 0.8 & Moderately High \\
\hline 5. & I make sure that I submit quality work on time. & 3.79 & 0.9 & Moderately High \\
\hline 6. & $\begin{array}{l}\text { I make time for my school work despite busy } \\
\text { schedules. }\end{array}$ & 3.77 & 0.85 & Moderately High \\
\hline 7. & I make sure that I have advanced readings over a topic. & 3.57 & 0.85 & Moderately High \\
\hline 8. & I allot time to study lessons every night. & 3.55 & 0.97 & Moderately High \\
\hline 9. & I budget time for each subject to study. & 3.61 & 0.89 & Moderately High \\
\hline 10. & I make sure that learning is a responsibility. & 3.86 & 0.98 & Moderately High \\
\hline \multicolumn{2}{|c|}{ Overall } & 3.72 & $\mathbf{0 . 3 2}$ & Moderately High \\
\hline
\end{tabular}




\section{Appendix G}

The Level of their Self-Regulation as to Organizing

\begin{tabular}{lllll}
\hline Indicator & X & SD & Interpretation \\
\hline 1. $\quad$ I determine how to solve a problem before I begin. & 3.93 & 0.84 & Moderately High \\
2. $\quad$ I think through my mind the steps of a plan that I have to follow. & 3.70 & 0.76 & Moderately High \\
3. $\quad$ I try to understand the goal of a task before I attempt to answer. & 3.85 & 0.79 & Moderately High \\
4. $\quad$ I ask myself questions about what a problem requires me to do to solve it, & 3.76 & 0.9 & Moderately High \\
5. $\quad$ I imagine the parts of a problem that I still have to complete. & & 3.76 & 0.89 & Moderately High \\
6. I carefully plan a course of action to solve a problem. & 3.78 & 0.87 & Moderately High \\
7. $\quad$ I figure out my goals and what I need to do to accomplish them. & 3.63 & 0.83 & Moderately High \\
8. I develop a plan for the solution of a problem. & 3.96 & 0.87 & Moderately High \\
9. $\quad$ I highlight important concepts and information I find in my readings. & 3.76 & 0.81 & Moderately High \\
10. $\quad$ I organize materials that I need to study. & 3.92 & 0.82 & Moderately High \\
\hline Overall & $\mathbf{3 . 8 1}$ & $\mathbf{0 . 3 1}$ & Moderately High \\
\hline
\end{tabular}

\section{Appendix $\mathbf{H}$}

Perception of the Respondents on Learning Performance in terms of Motivation

\begin{tabular}{|c|c|c|c|c|}
\hline \multicolumn{2}{|c|}{ Indicator } & \multirow{2}{*}{$\frac{\mathbf{X}}{4.00}$} & \multirow{2}{*}{$\frac{\text { SD }}{0.95}$} & \multirow{2}{*}{$\begin{array}{l}\text { Interpretation } \\
\text { Moderately High }\end{array}$} \\
\hline 1. & I study because it's good for me. & & & \\
\hline 2. & I study because of reward or grades. & 3.79 & 0.92 & Moderately High \\
\hline 3. & It is important to me to be smart. & 3.80 & 0.9 & Moderately High \\
\hline 4. & $\begin{array}{l}\text { I test myself on important topics until I understand them } \\
\text { completely. }\end{array}$ & 3.80 & 0.87 & Moderately High \\
\hline 5. & I learn more if it is without fear. & 3.90 & 0.97 & Moderately High \\
\hline 6. & I want a self-directed learning. & 3.73 & 0.9 & Moderately High \\
\hline 7. & I visualize my own learning. & 3.73 & 0.93 & Moderately High \\
\hline 8. & I perform well in a competition. & 3.96 & 0.9 & Moderately High \\
\hline 9. & I love to hear feedback of my learning. & 4.05 & 0.84 & Moderately High \\
\hline 10. & $\begin{array}{l}\text { I am good at problem-solving when it develops a solution } \\
\text { that works. }\end{array}$ & 3.71 & 0.9 & Moderately High \\
\hline Ove & & 3.80 & 0.39 & Moderately High \\
\hline
\end{tabular}




\section{Appendix I}

Perception of the Respondents on Learning Performance in terms of Cognition

\begin{tabular}{|c|c|c|c|c|}
\hline \multicolumn{2}{|c|}{ Indicator } & \multirow{2}{*}{$\frac{\mathbf{X}}{3.81}$} & \multirow{2}{*}{$\frac{\text { SD }}{0.85}$} & \multirow{2}{*}{$\begin{array}{l}\text { Interpretation } \\
\text { Moderately } \\
\text { High }\end{array}$} \\
\hline 1. & I am able to memorize concepts and ideas. & & & \\
\hline 2. & I can reason out based on the given facts. & 3.79 & 0.81 & $\begin{array}{l}\text { Moderately } \\
\text { High }\end{array}$ \\
\hline 3. & I am able to comprehend what I have read. & 3.85 & 0.83 & $\begin{array}{l}\text { Moderately } \\
\text { High }\end{array}$ \\
\hline 4. & I am able to internalize the message of an idea. & 3.83 & 0.85 & $\begin{array}{l}\text { Moderately } \\
\text { High }\end{array}$ \\
\hline 5 . & I am able to produce new ideas out of the given set. & 3.74 & 0.87 & $\begin{array}{l}\text { Moderately } \\
\text { High }\end{array}$ \\
\hline 6. & I can evaluate concepts and products. & 3.60 & 0.83 & $\begin{array}{l}\text { Moderately } \\
\text { High }\end{array}$ \\
\hline 7 & I can deliver messages from the given set. & 3.66 & 0.83 & $\begin{array}{l}\text { Moderately } \\
\text { High }\end{array}$ \\
\hline 8. & $\begin{array}{l}\text { I can see types of relationship that exists between ideas or } \\
\text { objects. }\end{array}$ & 3.75 & 0.81 & $\begin{array}{l}\text { Moderately } \\
\text { High }\end{array}$ \\
\hline 9. & I can read between the lines. & 3.64 & 0.83 & $\begin{array}{l}\text { Moderately } \\
\text { High }\end{array}$ \\
\hline 10. & I am able to control or manipulate my own learning. & 3.62 & 0.35 & $\begin{array}{l}\text { Moderately } \\
\text { High }\end{array}$ \\
\hline Ove & & 3.73 & 0.35 & $\begin{array}{l}\text { Moderately } \\
\text { High }\end{array}$ \\
\hline
\end{tabular}

\section{Appendix J}

Perception of the Respondents on Learning Performance in terms of Behavior

\begin{tabular}{|c|c|c|c|c|}
\hline \multicolumn{2}{|c|}{ Indicator } & \multirow{2}{*}{$\frac{\mathbf{X}}{3.84}$} & \multirow{2}{*}{$\frac{\text { SD }}{0.84}$} & \multirow{2}{*}{$\begin{array}{l}\text { Interpretation } \\
\text { Moderately High }\end{array}$} \\
\hline 1. & I learn through samples and patterns. & & & \\
\hline 2. & I get high scores in the test. & 3.71 & 0.78 & Moderately High \\
\hline 3.. & $\begin{array}{l}\text { I am a good performer in the group when the group } \\
\text { members have trust on me. }\end{array}$ & 3.71 & 0.86 & Moderately High \\
\hline 4. & I perform well when I am supervised. & 3.66 & 0.82 & Moderately High \\
\hline 5. & I perform well in a welcoming environment. & 3.71 & 0.97 & Moderately High \\
\hline 6. & I follow instruction well. & 3.69 & 0.89 & Moderately High \\
\hline 7. & I am good at recitation. & 3.56 & 0.88 & Moderately High \\
\hline 8. & Breaks or rest help me a lot to perform well in class. & 3.80 & 0.88 & Moderately High \\
\hline 9. & $\begin{array}{l}\text { I have different working skills when I find the work } \\
\text { challenging. }\end{array}$ & 3.73 & 0.82 & Moderately High \\
\hline 10. & I learn well in a well-arranged classroom. & 3.86 & 0.93 & Moderately High \\
\hline$\overline{O v}$ & & 3.73 & 0.24 & Moderately High \\
\hline
\end{tabular}




\section{References}

Barbosa et. al. (2017). Beyond the Personal Learning Environment: Attachment and Control in the Classroom of the Future. Interactive Learning Environments, 22(2), $146-164$.

Dent, L., \& Koenca, R. G. (2015). Self-direction and Factors Influencing Technology Use: Examining the relationships for the 21 st century workplace. Computers in Human Behavior, 28(6), 2075-2082.

Dodge, T. (2010). Personal Learning Environments: A Conceptual Landscape revisited. eLearning Papers, 35, 1-16.

Dotson, Rader (2015). Students' Engagement Literature Review (Department of Educational Research: Lancaster University, 2015).

Dullas, A.R. (2018). The Development of Academic Self.

Ebun, D. \& Magallanes, T. (2018). Academic Self-Regulation of STEM SHS Students of Divine Word Colleges in Region I, Philippines and their Academic Performance. Texila International Journal of Academic Research. 5(1)

Farrington, et al. (2012). Teaching Adolescents to Become Learners. The Role of NonCognitive Factors in Shaping School Performance: A Critical Literature Review. Chicago, IL: University of Chicago Consortium on Chicago School Research.

Flanagan, L. J. "Why Understanding Obstacles is Essential in Achieving Goals?" (2014). Mindshift, KQED.

Garcia, A.V. (2017). Factors affecting students' academic performance. SunStar Pampanga

Ghorbani, N (2011). Individualist and Collectivist Values: Evidence of Compatibility in Iran and the United States. Personality and Individual Differences, 35, 431-447.

Hayon, C. W. (2008). Helping Students Develop Self-Regulated Learning Strategies. Retrieved from http://bigenhoc.wordpress.com/2010/02/24/helping-students-developself-regulated-learning-habits/

Kistner, M. H. (2010). Helping Students Become More Self-Regulated Learners. Students in Public Secondary Schools in Nairobi County, Kenya. School of Education, Kenyata University.

Lane G. Lansangan, M., G. Baking, E., T. Quiambao, D., C. Nicdao, R., V. Nuqui, A., C. Cruz, R.(2015). Correlates of students' academic performance in intermediate level Journal of Business \& Management Studies, 1(2). 1-7

Lester, Derek K. (2011): "Environmental Engagement Demand Differences within and among Holland Academic Environments" (Las Vegas: University of Nevada, 2011), 24.

Mangaoil, Armina B. (2018). "Psychological Factors and the Academic Performance among High School Students: Basis for Academic Self-Engagement Program" in SIPATAHOENAN: South-East Asian Journal for Youth, Sports \& Health Education, Volume 4(2), October, pp.139-150. Bandung, Indonesia: Minda Masagi Press owned by ASPENSI with a print-ISSN 2407-7348.

Mintz, Ethan Yazzie (2009). Charting the Path from Engagement to Achievement: A Report on the 2009 High School Survey of Student Engagement. Indiana: Indiana University, 2009.

Patrick et. al. (2009). Enhancing Motivation and Self-Regulated Learning in Multimedia Environments. In R. D. Koo, B. C. Choi, M. R. D. Lucas, \& T. C. Chan (Eds.), Education Policy, Reform, and School Innovations in the 
Asia-Pacific Region (pp. 525-547). Hong Kong: Association for Childhood Education International/Hong Kong y Macao (ACEI-HKM).

Porferio M. Almerino, Lanndon A. Ocampo, Dharyll Prince M. Abellana, Jana Gloria F. Almerino, Irene O. Mamites, Lilibeth C. Pinili, Janine Joy L. Tenerife, Regina E. Sitoy, Limuel J. Abelgas, Emerson D. Peteros, "Evaluating the Academic Performance of K-12 Students in the Philippines: A Standardized Evaluation Approach", Education Research International, vol. 2020, Article ID 8877712, 8 pages, 2020. https://doi.org/10.1155/2020/8877712

Rio et. al. (2017). Going Beyond Test-taking Strategies: Building Self-regulated Students and Teachers. Journal of Curriculum and Instruction, 1(1), 31-47.

Sanchez, A.A. (2016). Towards the Development of a Transformative Leadership Framework in Curriculum Implementation. Philippine Normal University.

Schraw, A. \& Mossman, S. H. (2016). Issues in Educational Research. University of Mazandaran, Iran.

Schunk, H. (2010). Innovative Ways for using GStudy to Orchestrate and Research Social Aspects of Self-Regulated Learning. Computers in Human Behavior, 26(5), 794805.

Sicat, Gerardo P.; Panganiban, Marian (2009): High school background and academic performance, UPSE Discussion Paper, No. 2009,05, University of the Philippines,

School of Economics (UPSE), Quezon City

Sozler (2012). Students' Engagement Literature Review Department of Educational Research: Lancaster University, 2012.

Turingan, J. P., Yang, Y. (2009). A Cross-cultural Comparison of Self-regulated Learning Skills between Korean and Filipino College Students. Asian Social Science. Vol. 5, No. 12.

William and Black (2010). Assessment and Classroom Learning. School of Education, King's College London, Cornwall House, Waterloo Road, London.

Wolters, C.A., Pintrich, P.R. \& Karabenick, S.A. (2013). Indicators of Positive Development: Definitive Measures and Prospective Validity.

Yiğittir, S. (2010). Values That Parents of the Primary Pupils Demand to be Educated in School, Journal of Values Education, 8(19), 207-223.

Zarie, A.A. \& Hatam, G. (2012). On the relationship between Self-Regulated Learning Components and L2 Vocabulary Knowledge and Reading Comprehension. Academy Publisher, Finland.

Zimmerman, B.J. (2010). "Becoming a Self-regulated Learner: An Overview. Theory into Practice", 41(12), 64-20

Zumbrunn, S., Tadlock, J. \& Roberts, E.D. (2011). Encouraging Self-regulated Learning in the Classroom: A Review of Literature. Metropolitan Educational Research Consortium (MERC). 